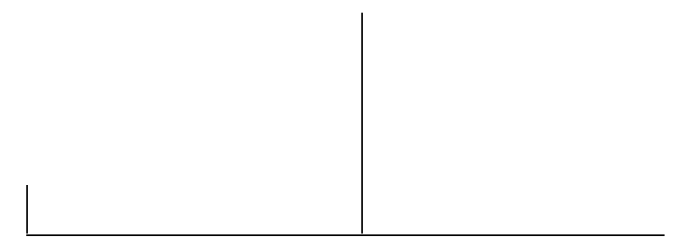

Rev. Latinoam. Psicopat. Fund., São Paulo, v. 14, n. 4, p. 660-671, dezembro 2011

\title{
Schizophrenia and violent behavior
}

\author{
Alexandre Martins Valença \\ Antonio Egidio Nardi \\ Isabella Nascimento \\ Talvane de Moraes \\ Mauro Mendlowicz
}

The aim of this study is to report the case of a woman who killed a child. After a forensic psychiatric appraisal to evaluate penal responsibility, she was considered not guilty by reason of insanity and mandatorily committed to the central forensic psychiatric hospital in the State of Rio de Janeiro, Brazil. The patient received a diagnosis of paranoid schizophrenia, based on DSM-IV-TR. She was not in psychiatric treatment and showed psychotic symptoms before the violent behavior became manifest. The study of motivational factors in homicidal behavior may provide further knowledge for understanding, preventing and treating it in such cases.

Key words: Crime, violence, murder, mental disorder 
Violence committed by individuals with severe mental disorders has increasingly called the attention of physicians, law enforcement officials and the general public. Various studies conducted in the last decade have shown an association between mental disorders and violent behavior (Hodgins et al., 1996; Mullen et al., 2000; Swanson et al., 1990). One of the principal approaches to studying this relationship is the evaluation of homicidal individuals, since murder is considered the most serious manifestation of violent tendencies.

In studying the relationship between mental disorders and homicide, one major concept is that of "abnormal" homicide, so called due to its bizarre and incomprehensible nature. It is also recognized as such when the psychiatric examination reveals that the perpetrator presents a severe mental disorder. The incidence of abnormal homicide tends to be consistent in various societies, running parallel to that of the principal mental disorders, whereas the incidence of "normal" homicide reflects the broader aspects of a given society, such as urban violence (Petursson and Gudjonsson, 1981).

A number of studies have investigated specific groups of patients with mental disorders with the view to establishing correlations between violent behavior or homicide and sociodemographic and psychopathologic variables. In this respect, with no doubt, schizophrenia is a well studied mental disorder. Schanda et al. (2004) in an Austrian study, investigated the frequency of mental disorders in individuals who committed homicidal acts for a period of 25 years (1975 to 1999), resulting in 896 convictions and 96 cases of involuntary commitments. The mental disorders most frequently found were schizophrenia or schizophreniform disorder ( $4.5 \%$ of men and $17 \%$ of women); major depressive episodes $(0.7 \%$ of men and $5.6 \%$ of women) and delusional disorders $(0.4 \%$ of 


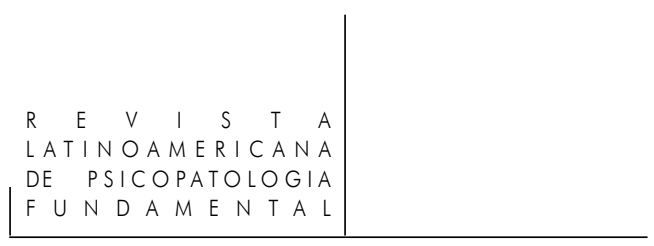

men). Of the individuals with severe mental disorders, a significantly higher proportion of men $(77.4 \%)$ and women $(70.8 \%)$ were diagnosed with schizophrenia. Thus, the risk of homicidal behavior was 6 times greater in men and 26 times greater in women, when compared to healthy individuals, with a predominance of the paranoid subtype (63\% in men and $47 \%$ in women).

A study based on the evaluation of $485(70 \%)$ of the 693 homicides committed over an eight-year period in Finland revealed that $6 \%$ of the samples presented schizophrenia, $2 \%$ presented other psychoses, and 33\% presented a personality disorder (Eronen et al., 1996). The authors also found that the risk of homicidal acts was greater among individuals presenting certain mental disorders (9.7 times greater for men with schizophrenia, 9 times greater for women with schizophrenia and 1.9 times greater for men with depression) than among healthy members of the population. It should be borne in mind that only some studies evaluated personality disorders.

Wallace et al. (2004) examined the criminal records of 2.861 individuals first hospitalized for schizophrenia between 1975 and 2000, comparing them to an equal number of individuals residing in the same community, matched for age, gender and region of inhabitation. Violent acts were defined as aggression, violence resulting in serious bodily harm or murder. The authors observed convictions for at least one violent act in a significantly higher percentage of individuals with schizophrenia than of those without schizophrenia residing in the same community ( $8.2 \%$ and $1.8 \%$, respectively). Another significant finding was that more substance abusers were convicted of crimes than were those who did not use drugs ( $68 \%$ and $11.7 \%$, respectively). The risk of being convicted of at least one violent act was found to be 3.6-6.6 times greater among individuals with schizophrenia than among the controls.

Researching this same subject, Côté and Hodgins (1992) interviewed 460 interns of the prisons of Quebec-Canada, using a standard diagnostic instrument (Diagnostic Interview Schedule). It was found that 109 individuals presented some form of severe mental disorder: 31 cases of schizophrenia, 4 cases of schizophreniform disorder, 51 cases of major depression, 21 cases of bipolar disorder and 2 cases of organic-mental disorder. Another important finding of this study was that the homicide group, compared to the non-homicide, had a greater prevalence of schizophrenia and lower prevalence of drug abuse/dependence and antisocial personality disorder.

Some authors have found that $45 \%$ of the cases of violent behavior among individuals with schizophrenia are directly related to the symptoms of this mental disorder (Taylor, 1985; Junginger, 1996). Certain psychotic symptoms, such as persecutory delusions (Swanson et al., 1997) and auditory hallucinations (Junginger, 1996), have been shown to be more strongly associated with violent 
behavior. However, other authors have found no association between active psychotic symptoms and violent behavior (Appelbaum et al., 2000). One explanation for this is that, in individuals with previous tendencies toward violent behavior or homicide, the risk for such behavior increases when they develop a psychosis. Therefore, evaluating the symptoms associated with acts of aggression can be useful is assessing the risk for violent behavior in such patients.

Now we present a case of a woman who killed a child. After a forensic psychiatric appraisal to evaluate the penal responsibility, she was considered not guilty by reason of insanity and is interned in a secure mental hospital in Rio de Janeiro, Brazil.

\section{Case report}

Female, 61 years old, black, single, maid working in residences, primary education.

In 1997 the patient was accused, together with two others individuals, of being members of a religious sect, called "Noah's Ark", keeping a child in unlawful captivity and with no food, for seven days. The child died. Another four children (these the patient's grandsons) were also being kept in unlawful captivity, but were discovered in time and were able to be saved. The patient informed that at this time she was hearing voices telling messages in her mind, that she attributed to "the holy spirit". She informed that in these messages the "holy spirit" gave her guidance to abandon everything, in order to dedicate herself to him completely, and to create a church and to do charity to her neighbourhood.

The patient informed that ever since she has followed the "orders", she abandoned her job as a maid working in residences. She assumed a life exclusively dedicated to religious activities. She informed that received ill people in the church and used to help them, in her own words, "everything with the will of the holy spirit". The patient said that the reason for her imprisonment was the death of a child in the church, a child who the patient alleged was passing through a "purification treatment" ordered by the "holy spirit". She further explained that this child "passed away" because the "holy spirit" ordered that she should keep the child in a bed receiving just bread and water as treatment.

The patient had never undertaken any psychiatric treatment, such as interned in a hospital or through an ambulatory psychiatric service. In the forensic psychiatric appraisal, she presented delusions of a mystical content and imperative auditory hallucinations, stating that the "holy spirit" commanded her to keep the child remaining in a state of purification, which meant lying down without food. 


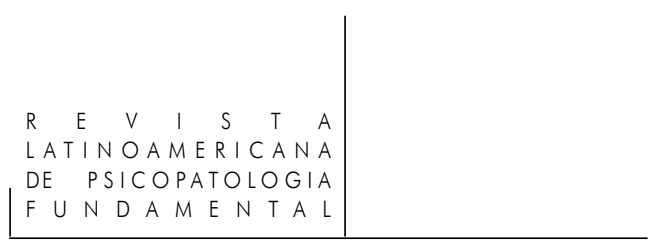

There was no record or report of use of alcohol and/or drugs. The patient was considered not guilty by reason of insanity, in the light of her mental illness, paranoid schizophrenia (DSM-IV-TR, 2000) and has been interned in a secure mental hospital in Rio de Janeiro, Brazil, for the last twelve years.

A recent psychiatric exam, related to the present study, found that there is a persistence of delusions and auditory hallucinations, when she affirmed that "all of us that were in the ark would be able to leave with the permission of the holy spirit. I have to follow his work and carry out purification of the gospel. The false gods are going to go out of circulation. The holy spirit told me to say that no one remained imprisoned in the ark and that everyone could leave with his permission".

\section{Discussion}

In Brazil, the criteria adopted by the penal code (1998) for the evaluation of penal responsibility is biopsychological: the responsibility is only excluded, if the agent, in view of mental illness or mental retardation, was, at the moment of the act, incapable of legal-ethic understanding and of self-determination. The biopsychological method demands verification of the effective existence of a causality nexus between anomalous mental state and the crime practised. This state, contemporary to the conduct, should deprive partially or completely the agent of any mentioned psychological capacities (be they intellectual or volitional). At the time of the occurrence (crime committed), the patient presented an important alteration of reality judgement (incapacity to understand the unlawful characteristic of the facts), as well as incapacity to choose more appropriate forms of behaviour, from social and moral point of view (incapacity of determination).

This case of paranoid schizophrenia illustrates well how in the presence of psychotic symptomatology, these individuals may present a risk of aggressive behaviour. One perceives in this case that the motivation for the crime resulted from the hallucinatory-delusional symptomatology presented by the patient. Faulk (1994) states that there may be a direct relationship between a crime and the psychopathological phenomenon created by the mental illness. This arises when the behaviour of the individual is directed by hallucinations, thinking disorders or delusions, as in the case under consideration. According to the MacArthur Violence Risk Assessment (Monaham et al., 2001), a study that focused on the identification of specific risk factors for violence among psychiatric populations, the presence of auditory hallucinations, specifically if voices command a violent act, the likelihood of violence is increased, which is present in this case. 
A study by Taylor (1985) found a strong association between the psychotic symptoms and recent violent behavior, since $93 \%$ of the samples presented psychotic symptomatology when they committed their crimes and $47 \%$ were "definitively" or "probably" motivated by these crimes. Other studies have found an association between auditory hallucinations and persecutory delusional ideas and homicidal motivations (Link and Stueve,1994; Beck, 2001; Cheung et al., 1997). Delusions noted to increase the risk of violence were those characterized by threat/control override symptoms. These delusions may involve the belief that the mind is dominated by forces beyond the person's control (Harris and Lurigio, 2007), which is also present in this case. The patient believed she was commanded by the "holy spirit" and her life was totally dedicated to that religious delusion.

Tiihonen (1993) undertook a study, in Finland, of all the people that had been imprisoned for homicide from June 1990 to May 1991. It was verified that between men that had committed homicide, schizophrenia was 6.5 times more prevalent that in the population in general. Among the women, it was 1.5 times more prevalent. The majority of crimes committed by schizophrenics occur in the family environment in the initial phase of the illness. In the case of the patient in question, she also kept her grandsons in unlawful captivity.

In an epidemiological study with almost 40,000 participants, Elbogen and Johnson (2009) investigated the risk factors that prospectively predicted violent behaviour. It was found that individuals with severe mental health disorders and substance abuse and/or dependence posed a higher risk than individuals with either of these disorders alone. In other words, the incidence of violent behaviour, though slightly higher among people with severe mental illness, was only significantly so for those with comorbid substance abuse, this association being considered a robust predictor of violent behaviour.

Valença (2008) studied a sample of all female patients with psychotic disorders who were acquitted by reason of insanity of murder $(n=5)$ or attempted murder $(\mathrm{n}=3)$ and involuntarily committed to the main forensic psychiatric hospital in the state of Rio de Janeiro, Brazil. Seven patients received a diagnosis of schizophrenia and one schizoaffective disorder. In total there were ten victims assaulted. Most victims $(n=6)$ were family members of patients. According to initial psychiatric forensic evaluation, five of the total sample $(n=8)$ had psychotic symptoms at the time of this evaluation. It was observed that auditory hallucinations $(n=4)$ were the most common psychotic symptoms in this group, according to expert assessment.

Several studies have found a recurring pattern of loss of contact with the mental health services, while in other studies the homicide seems to occur immediately after the first mental disorder episode, before the offender had established a contact with these services (Meehan et al., 2006). It is important 


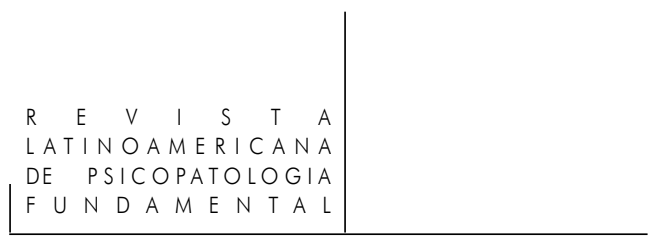

that mental health services work to prevent the loss of contact and non adherence to treatment that frequently precedes the violent behavior committed by people with severe mental disorders. Furthermore it is fundamental that society and government authorities attenuate the barriers of access to psychiatric and psychosocial treatment.

\section{Conclusions}

Ideally, studies on violent behavior related to schizophrenia should be prospective in nature (Volavka et al., 1997). The dependent variable (violence) should be carefully defined and related information should be selected from multiple factors, including self-reporting, information from relatives, assistance services and the legal authorities. The effects of the prescribed anti-psychotic medications and the adherence of patients to this treatment and psychosocial ones should be included among the information to be obtained.

It is important that psychiatrists and other mental health professionals be alert to the risk of violent behavior in patients with schizophrenia, especially in the presence of commanding auditory hallucinations of a violent act. Individuals who are at risk for displaying violent behavior should be identified, and mental health treatment services should be made available to them. The study of motivating factors of homicide behavior may offer knowledge that will assist the establishment of therapeutic interventions for women with mental disorders who represent risk of this nature or other forms of violent behavior.

\section{References}

American Psychiatry Association. Diagnostic and Statistical Manual of Mental Disorders ( $4^{\text {rd }}$ ed. Text Revised). Washington: American Psychiatric Association, 2000 .

Appelbaum, P.S; Robbins, P.C.; Monahan, J. Violence and delusions: data from the MacArthur Violent Risk Assessment study. American Journal of Psychiatry, v. 157, n. 4, p. 566-572, 2000.

BECK, J.C. Delusions, substance abuse, and serious violence. 20 The journal of the American Academy of Psychiatry and the Law, v. 32, p. 169-172, 2001.

Cheung P.; Schweitzer, I.; Crowley, K. et al. Violence in schizophrenia: role of hallucinations and delusions. Schizophrenia research, v. 26, p. 181-190, 1997. 
Código de Processo Penal. 3rd. edition. São Paulo: Ed. Revista dos Tribunais, 1998.

CôTÉ, G.; Hodgins, S. The prevalence of major mental disorders among homicide offenders. International Journal of Law and Psychiatry, v. 15, n. 1, p. 89-99, 1992.

Elbogen, E.B.; Johnson, S.C. The intricate link between violence and mental disorder. Archives of General Psychiatry, v. 66, n. 2, p. 152-161, 2009.

Eronen, M.; Hakola, P.; Timonen, J. Factors associated with homicide recidivism in a 13-year sample of homicide offenders in Finland. Psychiatric services, v. 47, n. 4, p. 403-406, 1996.

FaulK, M. Basic Forensic Psychiatry. London: Blackwell Scientific Publications, 1994.

HaRris, A.; LuRIGIO, A.J. Mental illness and violence: a brief review of research and assessment strategies. Aggression and violent behavior, v. 12, p. 542-551, 2007.

Hodgins, S.; Mednick, S.A.; Brenann, P.A. et al. Mental disorder and crime. Evidence from a Danish birth cohort. Archives of General Psychiatry, v. 53, n. 6, p. 489-496, 1996.

JuNGINGER, J. Psychosis and violence: the case for a content analysis of psychotic experience. Schizophrenia bulletin, v. 22, n. 1, p. 91-103, 1996.

LinK, B.G.; Stueve, A. Psychics symptoms and the violent/illegal behavior of mental disorders compared to community controls, in violence and mental disorder: developments and risk assessment. Chicago: University of Chicago Press, 1994.

Meenan, J.; Flynn, S.; Hunt, I. et al. Perpetrators of homicide with schizophrenia: a national clinical survey in England and Wales. Psychiatric services, v. 57, p. 1648$1651,2006$.

Monahan, J.; Steadman, H.; Silver, E. Rethinking risk assessment: The MacArthur study of mental disorder and violence. New York: Oxford University Press, 2001.

Mullen, P.E.; Burgess, P.; Wallace, C. et al. Community care and criminal offending in schizophrenia. Lancet, v. 355, n. 9204, p. 614-617, 2000.

Petursson, H.; Gudjonsson, G.H. Psychiatric aspects of homicide. Acta Psychiatrica Scandinavica, v. 64, n. 5, p. 363-372, 1981.

SChANDA, H.; KNeCht, G.; Schreinzer, D. et al. Homicide and major mental disorders: a 25-year study. Acta psychiatrica Scandinavica, v. 110, n. 2, p. 98-107, 2004.

Swanson, J.; Estroff, S.; Swartz, M. et al. Violence and severe mental disorder in clinical and community populations: the effects of psychotic symptoms, comorbidity, and lack of treatment. Psychiatry, v. 60, n. 1, p. 1-22, 1997.

Swanson, J.W.; Holzer, C.E.; Ganu, V. et al. Violence and psychiatric disorder in the community: evidence from the Epidemiologic Catchment Area Surveys. Hospital \& Community Psychiatry, v. 41, n. 7, p. 761-770, 1990. 


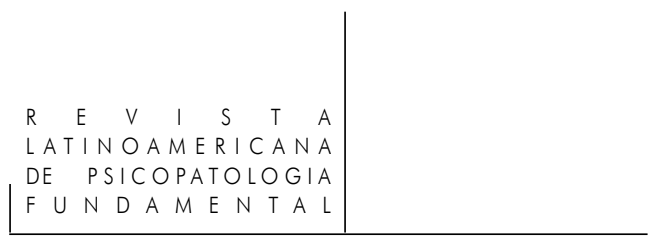

TAYLOR, P.J. Motives for offending among violent and psychotic patients. British Journal of Psychiatry, v. 147, p. 491-498, 1985.

TimHonen, J. Criminality associated with mental disorders and intellectual deficiency. Archives of General Psychiatry, v. 50, p. 917-918, 1993.

VALEnÇA, A.M. Aspectos psicopatológicos e forenses de mulheres homicidas com diagnóstico de transtornos psicóticos primários - estudo de série de casos. Jornal Brasileiro de Psiquiatria, v. 57, n. 4, p. 253-260, 2008.

Volavka, J.; LASKa, E.; BAKER, S. et al. History of violent behavior and schizophrenia in different cultures: analyses based on the WHO study on determinants of outcome of severe mental disorders. British Journal of Psychiatry, v. 171, p. 9-14, 1997.

Wallace, C.; Mullen, P.E.; Burgess, P. Criminal offending in schizophrenia over a 25-year period marked by deinstitutionalization and increasing prevalence of comorbid substance use disorders. American Journal of Psychiatry, v. 161, n. 4. p. 716-727, 2004.

\section{Resumos}

(Esquizofrenia e comportamento violento)

O objetivo deste estudo é relatar o caso de uma mulher que assassinou uma criança. Após uma avaliação psiquiátrico-forense para avaliação da responsabilidade penal, ela foi considerada inimputável por insanidade mental e involuntariamente internada em hospital psiquiátrico forense do estado do Rio de Janeiro, Brasil. A paciente recebeu diagnóstico de esquizofrenia paranoide de acordo com os critérios do DSM-IV-TR. Ela não estava em tratamento psiquiátrico e apresentava sintomas psicóticos antes da manifestação do comportamento violento. $O$ estudo de fatores motivadores do comportamento homicida pode fornecer conhecimentos para a sua compreensão, prevenção e tratamento, em casos como esse.

Palavras-chave: Crime, violência, homicídio, transtorno mental

(Schizophrénie et comportement violent)

Cette étude analyse le cas d'une femme qui a tué son enfant. Après l'évaluation psychiatrique médico-légale sur la responsabilité pénale, cette femme a été déclarée irresponsable en raison de son trouble mental et hospitalisée dans un hôpital de psychiatrie légale à Rio de Janeiro, Brésil. Cette patiente a été diagnostiquée comme schizophrène paranoïde selon la DSM-IV-TR. Au moment du crime, la patiente ne suivait pas de traitement psychiatrique et présentait plusieurs symptômes psychotiques. L'étude des facteurs de motivation du comportement meurtrier peut fournir des

Rev. Latinoam. Psicopat. Fund., São Paulo, v. 14, n. 4, p. 660-671, dezembro 2011 
indications importantes pour la compréhension, la prévention et le traitement de ce genre de cas.

Mots clés: Crime, violence, homicide, troubles mentaux

(La esquizofrenia y el comportamiento violento)

Este estudio relata el caso de una mujer que asesinó a un niño. Después de una evaluación psiquiátrica-forense para determinar la responsabilidad penal, se la consideró inimputable por razones de insanidad mental e fue compulsoriamente internada en el hospital psiquiátrico-forense de Río de Janeiro, Brasil. El cuadro de la paciente fue diagnosticado como esquizofrenia paranoide, según el DSM-IV-TR. La misma no estaba en tratamiento psiquiátrico y presentaba síntomas psicóticos antes de la manifestación de la conducta violenta. El estudio de los factores determinantes para el comportamiento homicida podría ofrecer pistas para la comprensión, prevención y tratamiento en casos similares.

Palabras claves: Crimen, violencia, homicidio, trastorno mental

Citação/Citation: Valença, A.M.; Nardi, A.E.; Nascimento, I.; Moraes, T.; Mendlowicz, M. Schizophrenia and violent behavior. Revista Latinoamericana de Psicopatologia Fundamental, São Paulo, v. 14, n. 4, p. 660-671, dez.2011.

Editor do artigo/Editor: Prof. Dr. Manoel Tosta Berlinck

Recebido/Received: 15.10.2010/10.15.2010 Aceito/Accepted: 2.2.2011 / 2.2.2011

Copyright: () 2009 Associação Universitária de Pesquisa em Psicopatologia Fundamental/ University Association for Research in Fundamental Psychopathology. Este é um artigo de livre acesso, que permite uso irrestrito, distribuição e reprodução em qualquer meio, desde que o autor e a fonte sejam citados/This is an open-access article, which permits unrestricted use, distribution, and reproduction in any medium, provided the original author and source are credited.

Financiamento/Funding: Esta pesquisa é financiada pelo Conselho Nacional de Desenvolvimento Científico e Tecnológico - CNPq e Fundação Nacional de Desenvolvimento do Ensino Superior Particular - FUNADESP/This research is funded by the National Counsel of Technological and Scientific Development - CNPq and by the National Foundation of Higher Particular Education Development - FUNADESP 
Conflito de interesses/Conflict of interest: Os autores declaram que não há conflito de interesses/The authors declare that has no conflict of interest.

\section{Alexandre Martins Valença}

Doutor em Psiquiatria pelo Instituto de Psiquiatria da Universidade Federal do Rio de Janeiro - IPUB/UFRJ (Rio de Janeiro, RJ, Br); Prof. Adjunto do Departamento de Psiquiatria e Saúde Mental da Universidade Federal Fluminense - UFF (Niterói, RJ, Br); Prof. Adjunto de Psiquiatria da Universidade Severino Sombra (Vassouras, RJ, Br); Psiquiatra Forense pela Associação Brasileira de Psiquiatria (Rio de Janeiro, RJ, Br); Pesquisador do Instituto de Psiquiatria da Universidade Federal do Rio de Janeiro (Rio de Janeiro, RJ, Br); Bolsista do Conselho Nacional de Desenvolvimento Científico e Tecnológico - CNPq (Brasília, DF, Br).

Rua Conde de Bonfim, 232/511 - Tijuca

20520-054 Rio de Janeiro, RJ, Brasil

Fone: (21) 2264-4394

e-mail: avalen@uol.com.br

\section{Antonio Egidio Nardi}

Doutor em Psiquiatria pelo Instituto de Psiquiatria da Universidade Federal do Rio de Janeiro - IPUB/UFRJ (Rio de Janeiro, RJ, Br); Prof. Associado do Instituto de Psiquiatria da Universidade Federal do Rio de Janeiro - UFRJ (Rio de Janeiro, RJ, Br); Livre Docente. Rua Conde de Bonfim, 232/511 - Tijuca

20520-054 Rio de Janeiro, RJ, Brasil

Fone: (21) 2264-4394

e-mail: antononardi@terra.com.br

\section{ISABELLa NASCiMENTo}

Doutora em Psiquiatria pelo Instituto de Psiquiatria da Universidade Federal do Rio de Janeiro - IPUB/UFRJ (Rio de Janeiro, RJ, Br); Médica Assistente e Pesquisadora do Instituto de Psiquiatria da Universidade Federal do Rio de Janeiro - UFRJ (Rio de Janeiro, $\mathrm{RJ}, \mathrm{Br}$ ).

Rua Conde de Bonfim, 232/511 - Tijuca

20520-054 Rio de Janeiro, RJ, Brasil

Fone: (21) 2264-4394

e-mail: inascimento@gbl.com.br

\section{Talvane Marins de Moraes}

Doutor em Psiquiatria; Livre Docente e Professor de Psiquiatria da Escola de Medicina e Cirurgia do Rio de Janeiro (Rio de Janeiro, RJ, Br) e do Departamento de Ética e Psiquiatria 
Legal da Associação Brasileira de Psiquiatria (Rio de Janeiro, RJ, Br); Professor de Psiquiatria Forense da Pós-Graduação do Instituto de Psiquiatria da Universidade Federal do Rio de Janeiro - IPUB/UFRJ (Rio de Janeiro, RJ, Br).

Rua Conde de Bonfim, 232/511 - Tijuca

20520-054 Rio de Janeiro, RJ, Brasil

Fone: (21) 2264-4394

e-mail: talvane@terra.com.br

\section{Mauro Vitor Mendlowicz}

Doutor em Psiquiatria pelo Instituto de Psiquiatria da Universidade Federal do Rio de Janeiro - IPUB/UFRJ (Rio de Janeiro, RJ, Br); Prof. Adjunto do Departamento de Psiquiatria e Saúde Mental da Universidade Federal Fluminense - UFF (Niterói, RJ., Br); Pesquisador do Instituto de Psiquiatria da Universidade Federal do Rio de Janeiro -

IPUB/UFRJ (Rio de Janeiro, RJ, Br); Bolsista do Conselho Nacional de Desenvolvimento Científico e Tecnológico - CNPq (Brasília, DF, Br).

Rua Conde de Bonfim, 232/511 - Tijuca

20520-054 Rio de Janeiro, RJ, Brasil

Fone: (21) 2264-4394

e-mail: mmendlowicz@yahoo.com 